\title{
A rare case of co-infection with pulmonary tuberculosis and oronasal actinomycosis*,**
}

\author{
Caso raro de coinfecção tuberculose pulmonar e actinomicose oronasal \\ Vitor Alexandre Oliveira Fonseca, Gustavo Reis, Carlos Alves, \\ Maria José Simões, Elvira Camacho, António Pinto Saraiva
}

\begin{abstract}
Oronasal actinomycosis is an infection seldom described in the literature, especially in the form of a co-infection with pulmonary tuberculosis. We report the case of a 48-year-old male admitted to the isolation ward due to active pulmonary tuberculosis, with a history of diabetes and alcohol abuse. While hospitalized, the patient complained of dysphagia and nasal regurgitation of food. The examination of the oral cavity revealed an oronasal fistula. The infecting agent was identified, and the treatment was successful. We also present a brief review of the literature, as well as a full description and discussion of the process of investigating this rare clinical case.
\end{abstract}

Keywords: Actinomycosis, cervicofacial; Tuberculosis, pulmonary; Oral fistula.

\section{Resumo}

A actinomicose oronasal é uma infecção raramente descrita na literatura, especialmente na forma de coinfecção com tuberculose pulmonar. Descrevemos o caso de um paciente de 48 anos de idade, admitido em enfermaria de isolamento por tuberculose pulmonar bacilífera, com história de diabetes e alcoolismo. Durante a internação, o paciente referiu queixas de disfagia e regurgitação alimentar por via nasal. 0 exame da cavidade oral revelou uma fístula oronasal. 0 agente infeccioso foi identificado, e o tratamento foi realizado com sucesso. Apresentamos também uma breve revisão da literatura e uma descrição e discussão completa do processo de investigação deste raro caso clínico.

Descritores: Actinomicose cervicofacial; Tuberculose pulmonar; Fístula bucal.

\section{Introduction}

Actinomycosis is a chronic suppurative bacterial infection characterized by multiple abscesses, fistulous pathways and fibrosis involving the face, neck, chest and abdomen. It is caused by Actinomyces spp., a group of anaerobic gram-positive saprophytic bacteria.(1) We presentt a rare case of co-infection with pulmonary tuberculosis, confirmed by sputum culture. During hospitalization, the patient presented complaints of dysphagia and nasal regurgitation of food after eating. The examination of the oral cavity revealed a large fistula of the palate due to Actinomyces spp. infection.

\section{Case report}

A 48-year-old white male, a construction worker, was admitted to the ER with complaints of fever and productive cough, together with night sweats, for two days. He had a history of diabetes, alcohol abuse and was a current smoker with an 80 pack-year smoking history. In addition, his dental health and hygiene were very poor.

He was acyanotic and presented normal respiration. The chest $\mathrm{X}$-ray (Figure 1) revealed an infiltrative consolidation in the middle and upper lobes of the right lung, suggestive of cavitation. The sputum smear microscopy showed

\footnotetext{
* Study carried out in the Department of Pulmonology, Hospital Nossa Senhora do Rosário - HNSR - Barreiro, Portugal. Correspondence to: Vitor A. O. Fonseca. Av. Movimento das Forças Armadas, s/n, 2830-094, Barreiro, Portugal.

Tel 3512121473 00. E-mail: vitor_fonseca@sapo.pt

Financial support: None.

Submitted: 3 March 2009. Accepted, after review: 5 May 2009.

** A versão completa em português deste artigo está disponível em www.jornaldepneumologia.com.br
} 
a large number of AFB, suggesting tuberculosis, which was confirmed by culture for Mycobacterium tuberculosis. He was admitted to the isolation ward and started on a quadruple anti-tuberculosis regimen with isoniazid, rifampin, ethambutol and pyrazinamide. Serology was negative for HIV-1 and HIV-2. Urine culture and multiple blood cultures were negative throughout the hospital stay.

On post-admission day 34 , the patient started to complain of dysphagia and nasal regurgitation of food after eating. The examination of the oral cavity revealed an ulcerous lesion of the palate, suggesting fistulization of the oral and nasal cavities (Figure 2).

Magnetic resonance imaging and CT scans of the head revealed a large osteolytic lesion in the hard palate and in the superior alveolar arcade, forming an oronasal fistula, with perforation of the lower segment of the nasal septum. There was also hypertrophy of the lymphoid and soft tissues in the retropharyngeal walls, suggesting an infiltrative lesion (Figure 3).

Aerobic, anaerobic and AFB cultures of the lesion were negative. The histological examination of the lesion revealed necrotic tissue and bone with colonies of a bacterial population with spores and hyphae, suggestive of Actinomyces spp.

In order to reach a definite diagnosis, a PCR of the biopsy was carried out, revealing Actinomyces naeslundii.

Treatment was initiated with penicillin G (24 million $1 \mathrm{U} /$ day), which reduced the palatal ulceration. The patient was then referred to the Department of Maxillofacial Surgery for further treatment. During the treatment for oronasal actinomycosis, smear sputum microscopy rapidly became negative for $M$. tuberculosis, and the patient was discharged on post-admission day 70 .

\section{Discussion}

Actinomyces spp. are anaerobic or aerotolerant (facultatively anaerobic), non-sporulating, gram-positive bacteria that tend to form branching rods and filaments and have a fermentative type of carbohydrate metabolism. ${ }^{(2,3)}$

Actinomyces spp. are commensals of the mouth cavity and the upper respiratory tract. Their presence in the oral and respiratory specimens does not necessarily signify clinical disease

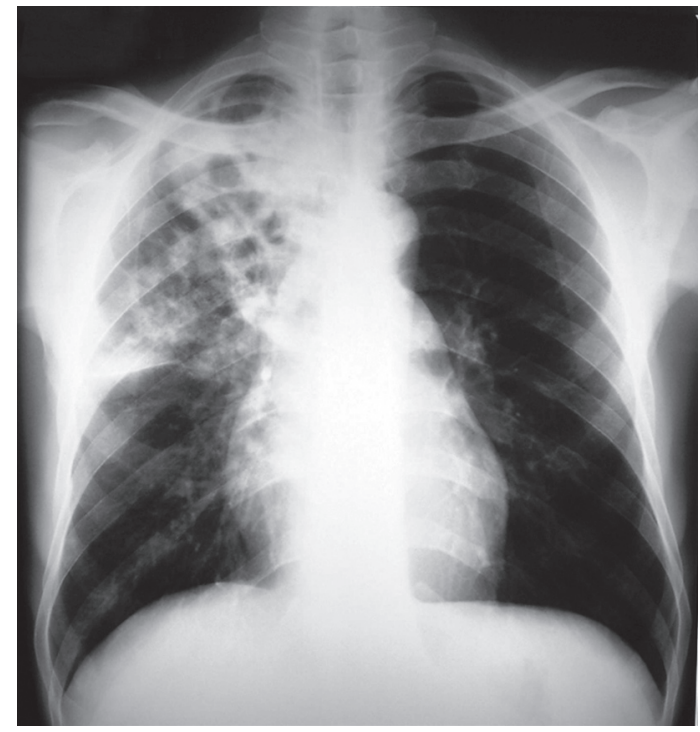

Figure $\mathbf{1}$ - Chest X-ray showing an infiltrative lesion and cavitation in the right upper lobe, consistent with tuberculosis.

and might often not be reported. In our case and in other cases described in the literature, a significant disease process was identified. ${ }^{(3)}$ We postulate that preexisting periodontal disease was the source of infection, which was exacerbated by alcohol consumption and diabetes. The pulmonary infection by $M$. tuberculosis was acquired by epidemiologic factors. Most infec-

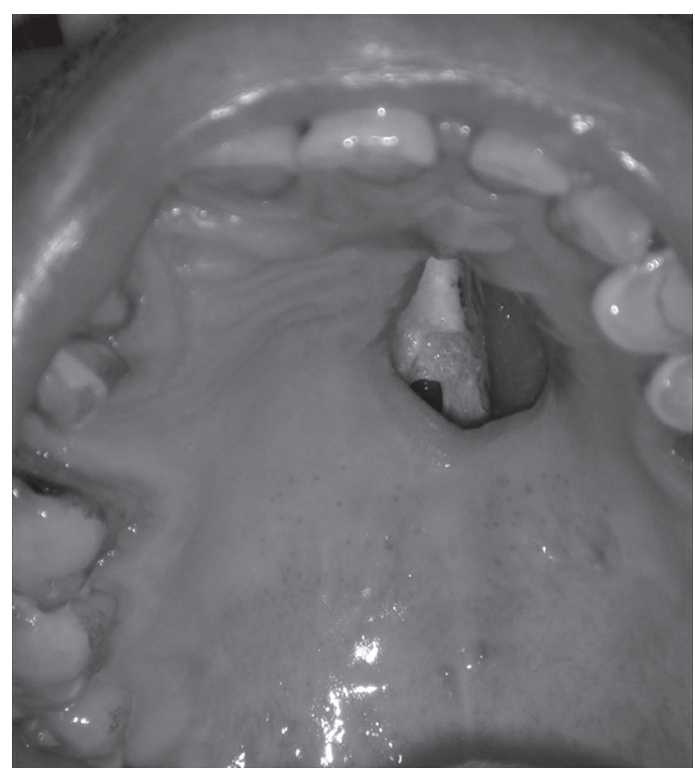

Figure 2 - Photograph of the oral cavity of the patient, revealing a large lesion in the hard palate with a fistula to the nasal cavity. The poor dental hygiene of the patient is also evident. 


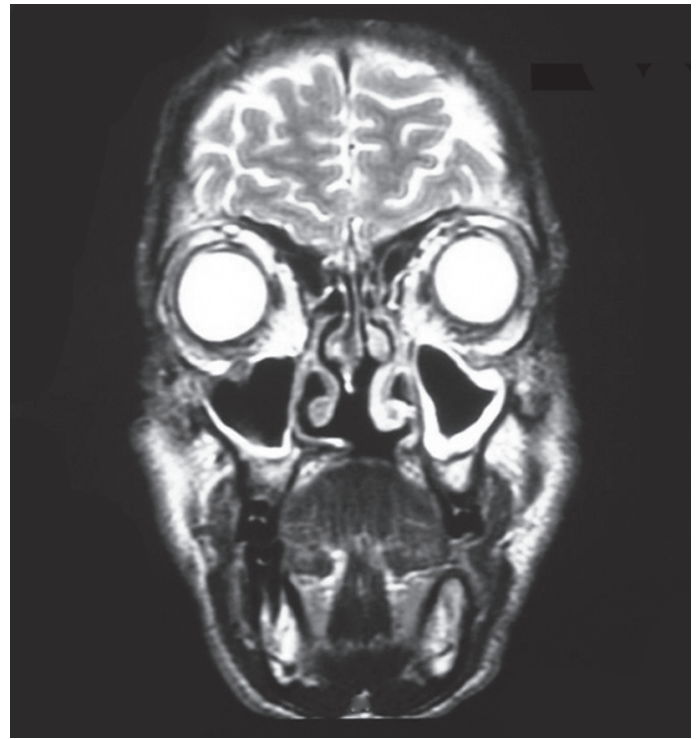

Figure 3 - Magnetic resonance imaging scan of the head revealing a large osteolytic lesion in the hard palate and in the superior alveolar arcade, forming an oronasal fistula, with perforation of the lower segment of the nasal septum.

tions with Actinomyces spp. are polymicrobial. ${ }^{(4)}$ The copathogens are most commonly colonizers of the respective involved organ systems. They act synergistically by inhibiting host defense mechanisms or reducing the oxygen tension in the affected tissue, which promotes the growth of Actinomyces spp. ${ }^{(4,5)}$

For the treatment of actinomycosis, the antibiotic of choice is penicillin, as shown in the majority of international guidelines. In this specific case, the antibiotic should have been administered orally. However, since an oral presentation of the antibiotic was not available in our country, the intravenous route was the initial choice. In severe or rapidly progressive cases, penicillin administration should be initiated intravenously. Other antibiotics (ampicillin, tetracycline and clindamycin) can be used orally with good treatment results. Due to the strong tendency toward recurrence of this infectious agent, the treatment should be extended to 6-12 months. ${ }^{(1)}$

In the literature, we found no reports of tuberculosis patients co-infected with $A$. naeslundii.

Resistance to antimycobacterial drugs is a common cause of therapeutic failure of tuberculosis. In the setting of full susceptibility, other entities such as a co-infection might be suspected and appropriate cultures obtained. The M. tuberculosis and Actinomyces spp. co-infection is rare and therefore presents a diagnostic challenge in clinical practice. Early identification prevents prolonged diagnostic and therapeutic interventions that increase health care costs. ${ }^{(2)}$.

\section{References}

1. Ferreira Dde F, Amado J, Neves S, Taveira N, Carvalho A, Nogueira R. Treatment of pulmonary actinomycosis with levofloxacin. J Bras Pneumol. 2008;34(4):245-8.

2. Tietz A, Aldridge KE, Figueroa JE. Disseminated coinfection with Actinomyces graevenitzii and Mycobacterium tuberculosis: case report and review of the literature. J Clin Microbiol. 2005;43(6):3017-22

3. Mabeza GF, Macfarlane J. Pulmonary actinomycosis. Eur Respir J. 2003;21(3):545-51.

4. Russo TA. Agents of actinomycosis. In: Mandell GL, Douglas RG, Bennett JE, Dolin R, editors. Principles and practices of infectious diseases. Philadelphia: Churchill Livingstone; 2000. p. 2645-54

5. Fishman, J. Approach to the Patient with Pulmonary Infection, In: Fishman AP, Elias JA, Fishman JA, Grippi MA, Senior RM, Pack Al, editors. Fishman's Manual of Pulmonary Diseases and Disorders. New York: McGrawHill; 2008. p. 1981-2015. 


\section{About the authors}

\section{Vitor Alexandre Oliveira Fonseca}

Intern. Complementary Internship Program in Pulmonology, Hospital Nossa Senhora do Rosário - HNSR - Barreiro, Portugal.

\section{Gustavo Reis}

Intern. Complementary Internship Program in Pulmonology, Hospital Nossa Senhora do Rosário - HNSR - Barreiro, Portugal.

\section{Carlos Alves}

Attending Pulmonologist. Complementary Internship Program in Pulmonology, Hospital Nossa Senhora do Rosário - HNSR - Barreiro, Portugal.

\section{Maria José Simões}

Attending Pulmonologist. Complementary Internship Program in Pulmonology, Hospital Nossa Senhora do Rosário - HNSR - Barreiro, Portugal.

\section{Elvira Camacho}

Head of the Department of Pulmonology, Hospital Nossa Senhora do Rosário - HNSR - Barreiro, Portugal.

\section{António Pinto Saraiva}

Head of the Department of Pulmonology, Hospital Nossa Senhora do Rosário - HNSR - Barreiro, Portugal. 